\title{
The Japan Library Association
}

\author{
Taro Miura \\ Meiji University, Chiyoda City, Tokyo, Japan
}

\begin{abstract}
The Japan Library Association (JLA) was established in 1892 following the establishment of American Library Association (ALA) in 1876, and Library Association (LA, now CILIP, the UK library and information association) in 1877 in the United Kingdom. JLA has been a leader in forming Japanese librarianship by organizing professional activities such as national conferences, local seminars, and publishing journals and books. This article describes the history and organization of JLA, and how JLA encourages Japanese librarians to develop professional skills.

Keywords: Library Association, Global Library Cooperation

Located in northeastern Asia, Japan is a Pacific Rim archipelago country with a total land area of $378,000 \mathrm{~km}^{2}$, including over 126 million people. The word for library is Toshokan in Japanese. Tosho means book, and suffix word -kan means building. Each city (population over 50,000) has its own public library. There are 3,296 public libraries (2018) offering library services to the public in Japan, in addition to three national libraries, 1,427 university libraries, and 37,979 school libraries. Almost all public libraries and academic libraries have their own public online catalog available via the Internet.
\end{abstract}

\section{HISTORY}

The first modern public library was opened in Japan around 1872 under the influence of western culture, although premodern open library has existed since $8^{\text {th }}$ century. Originally, the Japan Library Association (JLA) was founded in 1892 to promote library services and to cooperate librarians around Tokyo metropolitan areas. Mr. Tanaka Inagi decided to establish librarians' association with 24 founding members and was installed as the first president of JLA in 1900, when president system was introduced. JLA was established following the establishment of American Library Association (ALA) in 1876 and Library Association (LA, now CILIP) in 1877 in the United Kingdom. Initially, JLA was named Nihon Bunko Kyokai in Japanese, and was renamed Nihon Toshokan Kyokai in 1908. Bunko is the way of saying library in premodern period, and Kyokai means association. In 1903, the first JLA library seminar was held, to which over 50 librarians attended, studying clerical work. In 1906, JLA held the first All-Japan Library Conference, which was to be hold annually ever since, led by Mr. Wada Mannkichi, the second JLA president and professor of Tokyo University. JLA published Library Journal (Toshokan 
Zasshi) three times a year in the succeeding years (later switched to monthly publication.) These early efforts led to the further development of the Japanese librarianship. JLA started book selection for the standard catalog for public and school libraries in 1914. In 1929, JLA became a member of the International Federation of Library Associations and Institutions (IFLA).

In 1926, Board system was introduced. JLA became Incorporated Association in 1930 under the chairperson, Mr. Matsumoto Kiichi, the Librarian of National Library. The relationship between JLA and the Ministry of Education became strong, and the building of JLA was transferred to the premises of the Ministry of Education in 1933. In the same year, Library Imperial Ordinance (Toshokan Rei), which was enacted in 1899, was revised, and the regulation on public and private libraries was strengthened. During the 1930s-1940s, nationalism influenced the Japanese librarianship.

Japanese library system was reformed after World War II. A new Library Law (Toshokan Ho) was enacted in 1950 under the U.S. influence of the allied occupation (1945-1952). The law stipulated that public library was democratic institution and should be supported by tax, free of charge, and adequate to meet the information needs of the community. Some JLA individual members cooperated with American military officials in the enacting process. In the 1950s, library material organization tools were developed by JLA: Nippon Decimal Classification (NDC) $6^{\text {th }}$ ed. was published in 1950; Nippon Cataloguing Rules (NCR) in 1953; and Basic Subject Headings (BSH) in 1956. NDC was formerly published and revised by Mr. Mori Kiyoshi since 1929, influenced by Dewey Decimal Classification (DDC) system in USA, and JLA became responsible for its revision after the 1950s. In 1953, JLA also started to publish the Statistics on Libraries in Japan. As for intellectual freedom, "A Statement of Intellectual Freedom in Libraries" was adopted in 1954, claiming library autonomy in selecting and offering library materials and rejecting censorship. This statement was revised in 1979, adding protecting user's privacy in library, followed by the approval of 'Code of Ethics for Librarians' in 1980.

In mid-1960s, along with Japan's rapid economic growth, libraries began to undergo remarkable development. Mobile libraries, services for children, services for handicapped persons, audiovisual materials, and computers, were introduced. In 1963, JLA started the publication of a quarterly journal, Libraries Today (Gendai no Toshokan). Papers about specific research themes have been published on Libraries Today; short articles about recent topics or events have been published on Library Journal monthly. JLA published the report titled Management of Public Libraries in Small and Medium Cities, which is called Chu-sho Report in Japanese, and the book Citizen's Library (Shimin no Toshokan) in 1970. Chu-sho means small and medium libraries and Shimin refers to citizen. The report and the book focused on the service offering in libraries, not just storage of materials. In 1971, JLA adopted April $30^{\text {th }}$ as "Library Day" when Library Law (1950) has been promulgated on that day.

In 1980s, JLA expanded its operations and activities. From 1982, Library Yearbook has been published. JLA has been responsible for producing trend report in librarianship. JLA founded Library Architecture Award in 1985 and many new innovative libraries have received the award at the annual All-Japan Library Conferences since then. In August 1986, the $52^{\text {nd }}$ IFLA General Conference was held in Tokyo, Japan. JLA re-joined IFLA in 1952 after its withdrawal during 
WWII. Two thousand librarians from all over the world, including 1,500 Japanese librarians, attended the IFLA conference and discussed topics including library automation, electronic publishing, and multicultural services, etc. under the theme of "Toward $21^{\text {st }}$ Century Libraries." Aside from that, over 15,000 people came to the IFLA conference exhibition for four days. As for automation, JLA started the distribution of J-BISC in 1988, which is CD-ROM of the Japanese National Bibliography (JNB) of the National Diet Library (NDL).

JLA celebrated its $100^{\text {th }}$ anniversary in 1992 and held the $100^{\text {th }}$ memorial All-Japan Library Conference in Tokyo in 2014 (time-lag was from the conferences interrupted during WWII.)

\section{ORGANIZATION}

JLA is a non-profit organization representing the library profession in Japan. In 2014, JLA was repositioned as Public Interest Incorporated Association. The Council is the highest decisionmaking body of JLA. The Councilors are chosen by election among individual members. One councilor is elected per 100 individual members. The Board of Councilors meets twice a year to review JLA's budget and other important business matters. The Board of Councilors also elects members of the Board of Directors, which is the executive body of JLA. The Chairperson of the Board of Directors is the official representative of JLA. Mr. Mitsuhiro Oda, professor of Aoyamagakuin University, was newly inaugurated as the chairperson of the Board of Directors in June 2019. The Board of Directors (2019-2020) is consisted of 20 Directors, including Ms. Yoko Sakata, vice chair, Mr. Yutaka Ebine, executive director/managing director, and Mr. Koichi Hiruta, managing director.

Membership of the association is composed of four types: 3,296 individual members, 2,204 institutional members, 11 cooperate members and 56 supporting members (2019). Its activities have been supported by countless dedicated librarians for over 120 years. JLA represents all types of libraries and related information organizations in Japan. For professional activities, the present organization consists of six divisions: 1) The Public Library Division, 2) University Library Division, 3) Junior College Division, 4) School Library Division, 5) Special Library Division, and 6) Library and Information Education Division. Each individual member belongs to one of the six divisions. For those members in the Library and Information Education division, they can select one other division depending on their research areas. Chairpersons of the six divisions become members of the Board of Directors automatically.

For specific activities, there are 28 committees (2019). Each committee consists of one chair and about 5-10 individual members.

1. Library Policy Planning Committee

2. Copyright Committee

3. Intellectual Freedom Committee

4. Library Use Education Committee

5. Resource Preservation Committee

6. Services for Disabled People Committee 
7. Children and Young Adult Committee

8. International Relations Committee

9. Library Journal Editorial Committee

10. Libraries Today Editorial Committee

11. Library Yearbook Editorial Committee

12. Publishing Committee

13. Cataloging Committee

14. Classification Committee

15. Subject Headings Committee

16. Training Program Committee

17. Library Survey Committee

18. Library Facility Committee

19. Publishing Distribution Committee

20. Multicultural Committee

21. Health Information Committee

22. Certified Librarian Program Committee

23. Election Management Committee

24. Library Disaster Countermeasures Committee

25. Book Introduction Program Committee

26. Non-regular Employees Committee

27. Library Development in Japan (1993-2017) Editorial Committee

28. JLA Library Management Committee

\section{ACTIVITIES}

JLA developed the following activities to cooperate and coordinate all kinds of libraries and library organizations:

\section{Training for Library Staff}

JLA holds the three-day All-Japan Library Conference in different cities annually in each fall. Over 2,000 Japanese librarians have participated in meetings, workshops and exhibitions, and enjoyed cultural events during the annual conference. In November 2019, the $105^{\text {th }}$ All-Japan Library Conference will be held at Mie prefecture (http://105th-mietaikai.info/). In addition to the national conferences, JLA also carried out about 30 seminars and symposiums throughout the year, including step-up seminars for mid-career librarians, library basic courses, and seminars for several current topics. Since 2010, JLA has authorized Certified Librarian Program. A total of 150 librarians, who has ten years of experiences and gained over 20 points, have been certificated. Points could be earned by attending professional seminars, giving presentation at conferences, speaking at lectures, and so on. 


\section{Consultations and Support on Library Management and Policy Recommendations}

JLA has given advices on library management to newly established libraries and local authorities, and announced several policy recommendations, such as "A Way of Designated Manager System in Public Libraries (2016)," "Guidelines for Eliminating Discrimination Against People With Disabilities in the Library (2016)," "Improvement for the Environment of Character and Print culture (2006)," and so on.

\section{Research and Collection of Materials on Library Management, Operations, Services, and Technology}

JLA has conducted nation-wide surveys for public and academic libraries, publishing Library Yearbook and Japanese Libraries annually. The JLA Library collects materials on libraries, and library and information science, and holds about 10,000 monographs and 2,300 titles of periodicals, including conference proceedings, reports of committee meetings, Annual Reports of public libraries, architectural plans and booklets of various libraries. The Library is open to the public as well as JLA members. The reference and photocopy services are available to general public, though only members can borrow books.

\section{Creation and Dissemination of Library Management and Selection Tools}

JLA has revised information organizing tools: the latest versions are $N D C 10^{\text {th }} \mathrm{ed}$. (2014) for classification, NCR 2018 version for cataloging and BSH $4^{\text {th }}$ ed. (1999) for subject headings.

\section{Publication of Journals and Research Results}

Each year, JLA publishes 20 new titles concerning librarianship, including Library Practice Series with 40 titles, and Library and Information Text Series (now 11 volumes and the third season), in addition to Library Journal monthly and Libraries Today quarterly.

\section{Campaigns to Promote Library Progress and Awards for Contributions to Promoting Progress}

JLA has promoted library activities to the public and celebrated "Library Day" in April $30^{\text {th }}$. JLA has awarded the Library Architecture Award at the All-Japan Library Conferences since 1985.

\section{Collaboration, Cooperation, and Support With Domestic and Overseas Library Organizations}

JLA are affiliated with many regional library associations. JLA has been the Japanese national association member of IFLA since 1929.

\section{References}

Takayama, M., et al. (2017). Japan: Libraries, archives and museums. Encyclopedia in Library and Information Science, $4^{\text {th }}$ ed., CRC Press, 2560-2577. 
The Japan Library Association. The Japan Library Association.'

https://www.jla.or.jp/portals/0/html/jla-e.html\#jla

The Japan Library Association. Brief information on libraries in Japan.

https://www.jla.or.jp/portals/0/html/libraries-e.html\#general

About the author

Mr. Taro Miura is a Professor at the School of Arts and Letters, Meiji University, Japan. Professor Miura is also the Chair of International Relations Committee of JLA. His research focuses on modern Japanese library history and international cooperation of professional associations in the field of library and information science. 